\title{
Effect of Substitution at Amine Functionality of 2,6- Diaminopyridine-Coupled Rhodamine on Metal-Ion Interaction and Self-Assembly
}

\author{
Santanu Panja, Subhendu Mondal, Sourav Ghosh, Utpal Ghosh, and Kumaresh Ghosh*
}

Cite This: ACS Omega 2020, 5, 13984-13993

Read Online

ACCESS | Lill Metrics \& More | 回 Article Recommendations

| SI Supporting Information

ABSTRACT: 2,6-Diaminopyridine-coupled rhodamines 1 and 2 have been synthesized, and the effect of substitution on amine functionality toward metal-ion interactions and self-assembly is thoroughly investigated. Both the compounds effectively recognize different metal ions of biological significance fluorimetrically and colorimetrically with a high degree of selectivity and sensitivities. While compound $\mathbf{1}$ is sensitive to $\mathrm{Fe}^{3+}$ ions, compound 2 is
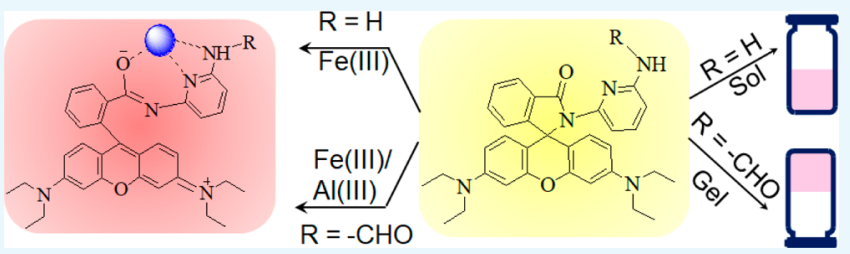
responsive to both $\mathrm{Fe}^{3+}$ and $\mathrm{Al}^{3+}$ ions in aqueous $\mathrm{CH}_{3} \mathrm{CN}$ (4/1, v/v; $10 \mathrm{mM}$ tris $\mathrm{HCl}$ buffer, $\mathrm{pH}$ 6.8). The sensing mechanism involves the metal-ion chelation-induced spirolactam ring opening of the rhodamine scaffold that results in both color and fluorescence changes, while the extent of interactions with the metal ions is truly governed by the chemical structure of the compounds. Both 1 and 2 are proficient in detecting $\mathrm{Fe}^{3+}$ and $\mathrm{Al}^{3+}$ ions in human lung cancer cells (A549). As new findings, unlike 1, compound 2 formed a faint pink gel in the toluene-hexane mixture solvent $(1: 1, \mathrm{v} / \mathrm{v})$, and the gel state of 2 selectively recognizes $\mathrm{Ag}^{+}$ ions by exhibiting a phase change from gel to purple sol. Experimental findings establish the role of the formamide moiety in forming the self-assembly.

\section{INTRODUCTION}

Since last few decades, the development of convenient and directly responsive techniques for recognition of ionic analytes has been desirable in the area of supramolecular chemistry because of their environmental and physiological relevance. ${ }^{1}$ In this endeavor, fluorogenic probes with suitable binding sites are preferable because of high selectivity and sensitivity of fluorescence particularly in the solution state. ${ }^{1 \mathrm{~b}, \mathrm{~d}, 2}$ In relation to this, colorimetric sensors are much convenient than fluorescent sensors as the recognition event can be read out visually without using any costly instrument. ${ }^{2 f, 3}$ Therefore, the construction of both fluorogenic as well as chromogenic probes is of special attention. ${ }^{3 \mathrm{~h}, \mathrm{i}, 4}$ In developing these probes, the use of rhodamine fluorochromes is notable for their excellent photophysical properties that include long absorption and emission wavelengths and high quantum yields. ${ }^{1 e, 5}$ For rhodamine compounds, the sensing is attributed to their metal ion-induced switching from the spiroring system (colorless) to the ring-opened form (pink colored, highly fluorescent). ${ }^{4 a, b, 6}$ In exploring metal-ion sensing, the use of rhodamine is stimulating although the event is somewhat solvent- and $\mathrm{pH}$-dependent.

In addition to these attributes, the stimuli-responsive selfaggregation behavior of the molecular architecture is often of considerable importance in reporting naked eye detection of ionic analytes. ${ }^{7}$ Compounds of this class require the presence of suitable functional groups with hydrophobic and hydrophilic balance in the backbone which encourages the formation of three-dimensional-crosslinked network in solution involving weak noncovalent interactions. Encapsulation of the solvent in such networks produces a highly viscous semisolid phase called the gel. Exploitation of this supramolecular gel in sensing involves the interaction of externally added ionic analytes with the gelator molecules that causes perturbation to the intermolecular forces occurring among the gelator molecules. As a consequence, the self-aggregated superstructure is destroyed, and the semisolid phase is converted into solution. Apart from the sensing study, supramolecular gels are incredibly important in the field of material to medicine. However, designing of such gelator molecules is complicated and receives increasing attention in material chemistry research. ${ }^{9}$ The literature survey reveals that, although huge numbers of rhodamine-based fluororeceptors are reported, ${ }^{1 \mathrm{e}, 5}$ only few are explored in gel chemistry. ${ }^{10}$ Rajasekar and Das has introduced a series of rhodamine- $N$-glycosylamine conjugates that form gels in various organic solvents. ${ }^{10 a}$ However, the use of rhodamine-based supramolecular gelators in sensing of the metal ion is completely unknown in the literature.

Received: March 27, 2020

Accepted: May 21, 2020

Published: June 3, 2020 
Herein, we report the synthesis of designed rhodaminecoupled 2,6-diaminopyridine $\mathbf{1}^{\text {5a }}$ and its derivative 2 toward metal ion sensing and self-assembly under different conditions. While in the semiaqueous medium compound 1 fluorimetrically as well as colorimetrically distinguished $\mathrm{Fe}^{3+}$ ions from other different metal ions examined, compound 2 exhibited strong interaction for $\mathrm{Fe}^{3+}$ and $\mathrm{Al}^{3+}$ ions under identical conditions. Both the compounds were eligible for in vitro detection of the said metal ions in human lung cancer cells (A549). Experimental results signified the role of the formamide moiety in stabilizing the adduct formation with metal ions. Incorporation of formamide functionality resulted in significant increase in the association constant values for compound 2 with $\mathrm{Fe}^{3+}$ and $\mathrm{Al}^{3+}$ ions.

Incorporation of the formamide moiety on $\mathbf{1}$ not only influenced the interaction strength toward metal ions but also allowed compound $\mathbf{2}$ to self-assemble into a fibrous structure involving intermolecular hydrogen bonding. Thus, compound 2 was capable of forming a faint pink gel in a nonpolar solvent $v i z$ toluene-hexane $(1: 1, \mathrm{v} / \mathrm{v})$. The metal ion responsiveness of 2 was significantly altered in the gel state compared to the solution state. The gel was transformed into sol with a color change from faint pink to deep violet selectively in the presence of an $\mathrm{Ag}^{+}$ion. To our opinion, this attribute is a firsttime report on $\mathrm{Ag}^{+}$ion sensing by a rhodamine-based gelator.

\section{RESULTS AND DISCUSSION}

Synthesis. Scheme 1 describes the synthesis of compounds $\mathbf{1}^{\mathrm{5a}}$ and 2 . The reaction of 2,6-diaminopyridine with rhod-

Scheme 1. (i) $\operatorname{POCl}_{3}$, 1,2-Dichloroethane, Reflux, 4 h; (ii) 2,6-Diaminopyridine, Dry $\mathrm{CH}_{2} \mathrm{Cl}_{2}, \mathrm{Et}_{3} \mathrm{~N}$, rt, $10 \mathrm{~h}$; (iii) Dry $\mathrm{CH}_{3} \mathrm{CN}$, Ammonium Formate, Reflux, $10 \mathrm{~h}$

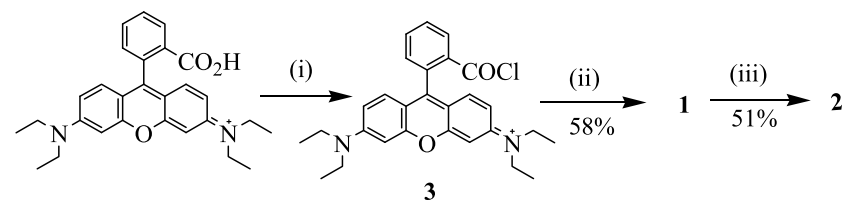

amine acid chloride 3 yielded the compound 1 , which on reaction with ammonium formate in dry acetonitrile afforded rhodamine-labeled formamide 2 . All the compounds were adequately characterized by different spectroscopic methods. Good quality crystals of the compound 2 were obtained from the $\mathrm{CH}_{3} \mathrm{OH}$ solvent, and the structure was solved by single crystal X-ray analysis (Figure $1 \mathrm{~b}$ ).

Metal Ion Binding in Solution. The metal-ion responsive behaviors of $\mathbf{1}$ and $\mathbf{2}$ toward different metal ions were studied in $\mathrm{CH}_{3} \mathrm{CN} / \mathrm{H}_{2} \mathrm{O}(4: 1, \mathrm{v} / \mathrm{v}, 10 \mathrm{mM}$ tris $\mathrm{HCl}$ buffer, $\mathrm{pH}=6.8)$. The binding interactions were followed using UV-vis, fluorescence, and nuclear magnetic resonance (NMR) spectroscopic tools. Before examining the interactions, the effect of $\mathrm{pH}$ on both the compounds 1 and 2 was studied. As can be seen from Figures S1 and S2, the solutions of 1 and 2 are colorless from $\mathrm{pH} 4$ to 12 . Below $\mathrm{pH} 4$, solutions become pink in color because of spirolactam ring-opening. The UV-vis spectra of $\mathbf{1}$ as recorded at different $\mathrm{pHs}$ reveal strong absorption at $560 \mathrm{~nm}$ in the $\mathrm{pH}$ range 2-3 because of the xanthenoid form of rhodamine (Figure S1b). Compound 2 exhibited a similar result (Figure S2b). Thus, the metal-ion interaction study of $\mathbf{1}$ and 2 was performed at $\mathrm{pH} 6.8$ where the spirolactam ring is retained.

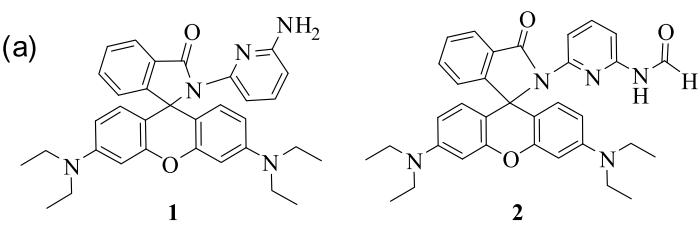

(b)

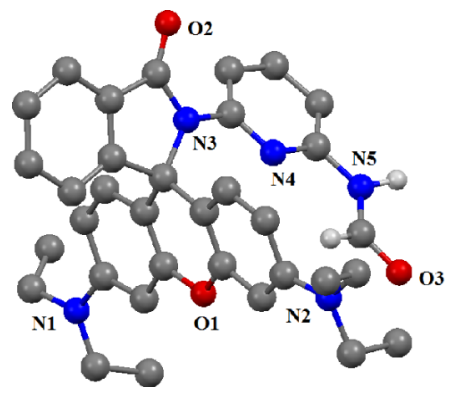

Figure 1. (a) Structures of compounds 1 and 2 and (b) single crystal $\mathrm{X}$-ray structure of compound 2. Hydrogen atoms are removed for clarity.

The change in emission of $\mathbf{1}$ was observed upon gradual addition of metal ions to the solution of 1 in aq. $\mathrm{CH}_{3} \mathrm{CN}$ $\left(\mathrm{CH}_{3} \mathrm{CN}: \mathrm{H}_{2} \mathrm{O}=4: 1, \mathrm{v} / \mathrm{v}, 10 \mathrm{mM}\right.$ tris $\mathrm{HCl}$ buffer, $\left.\mathrm{pH}=6.8\right)$. Compound 1 exhibited a weak emission at $570 \mathrm{~nm}\left(\lambda_{\mathrm{exc}}=480\right.$ $\mathrm{nm}$ ) which remained unperturbed upon interaction with all the metal ions examined except $\mathrm{Fe}^{3+}$ ions (Figure S3). Figure 2a, in

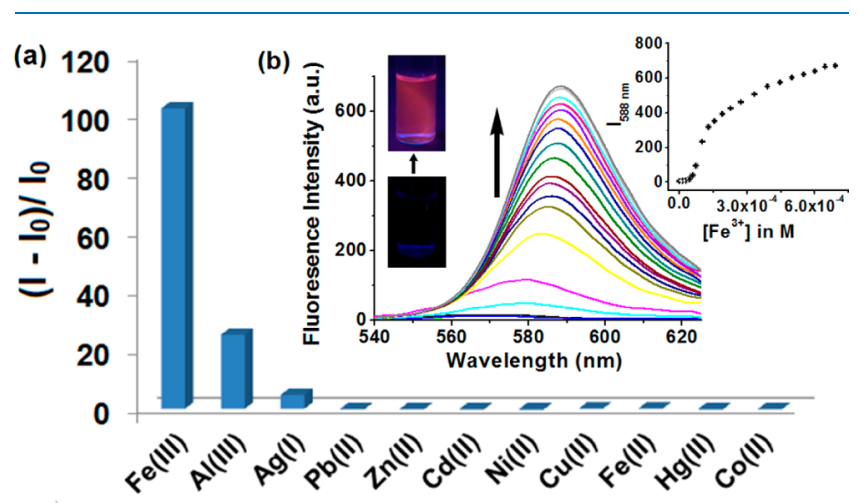

Figure 2. (a) Change in the fluorescence ratio of $1\left(c=3.80 \times 10^{-5}\right.$ $\left.\mathrm{M}, \lambda_{\mathrm{ex}}=480 \mathrm{~nm}\right)$ at $588 \mathrm{~nm}$ upon the addition of 20 equiv. amounts of metal ions $\left(c=3.0 \times 10^{-3} \mathrm{M}\right)$; (b) change in emission of 1 upon addition of 20 equiv amounts of $\mathrm{Fe}^{3+}$ ions in $\mathrm{CH}_{3} \mathrm{CN} /$ water $(4 / 1, \mathrm{v} /$ $\mathrm{v} ; 10 \mathrm{mM}$ tris $\mathrm{HCl}$ buffer, $\mathrm{pH}$ 6.8) (Inset: emission intensity of $\mathbf{1}$ as a function of $\mathrm{Fe}^{3+}$ ion concentration and related color change of the solution upon exposure to UV light).

this context, shows the change in the fluorescence ratio [ $(I-$ $\left.\left.I_{0}\right) / I_{0}\right]$ of 1 at $588 \mathrm{~nm}$ in the presence of 20 equiv amounts of the metal ions which suggests that compound $\mathbf{1}$ is more sensitive to $\mathrm{Fe}^{3+}$. In presence of $\mathrm{Fe}^{3+}$, the peak at $570 \mathrm{~nm}$ was intensified significantly and underwent a red-shift by $18 \mathrm{~nm}$ (Figure $2 \mathbf{b}$ ). Moreover, interaction of $\mathbf{1}$ with $\mathrm{Fe}^{3+}$ resulted in a color change of the solution from nonfluorescent to reddish brown under UV light.

As we move from compound $\mathbf{1}$ to $\mathbf{2}$, a different sensitivity for metal ions was observed in fluorescence. In this case, upon interaction with the metal ions, the nonemissive spectrum of 2 was disturbed significantly and furnished strong band at 585 $\mathrm{nm}$ selectively in the presence of both $\mathrm{Fe}^{3+}$ and $\mathrm{Al}^{3+}$ ions (Figure S4). Interaction with other metal ions produced no 

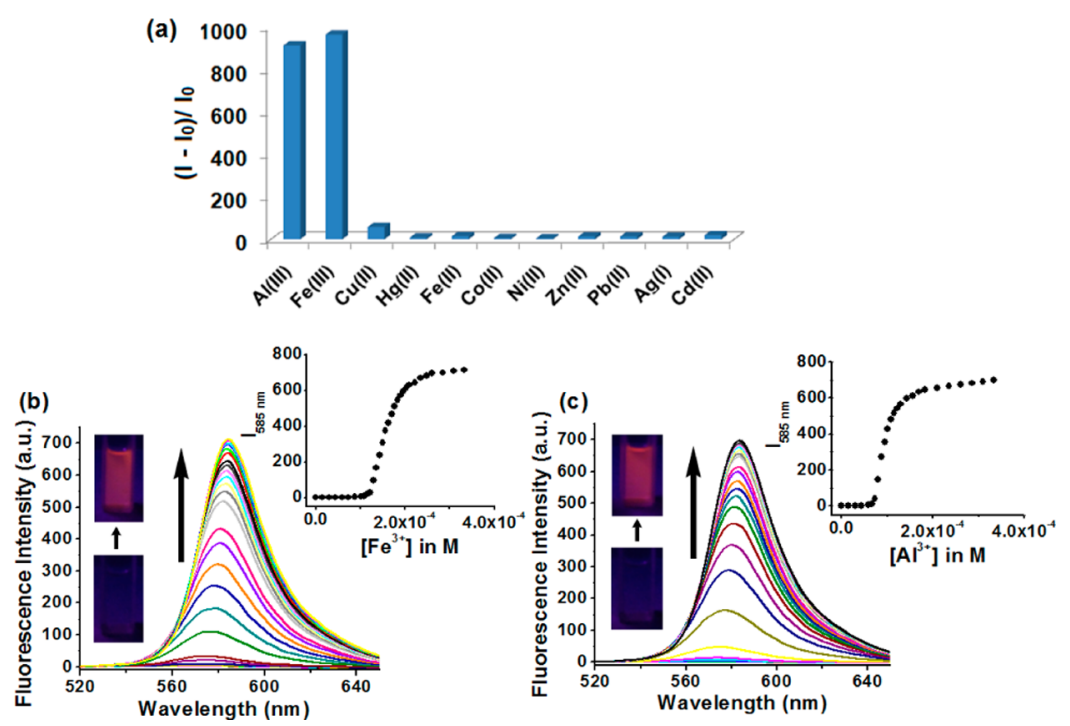

Figure 3. (a) Change in the fluorescence ratio of $2\left(c=3.80 \times 10^{-5} \mathrm{M}, \lambda_{\mathrm{ex}}=480 \mathrm{~nm}\right)$ at $585 \mathrm{~nm}$ upon addition of 10 equiv. amounts of metal ions $\left(c=3.0 \times 10^{-3} \mathrm{M}, \lambda_{\mathrm{ex}}=480 \mathrm{~nm}\right)$; Change in emission of $2\left(c=3.80 \times 10^{-5} \mathrm{M}\right)$ with 10 equiv. amounts of $(\mathrm{b}) \mathrm{Fe}^{3+}$ and $(\mathrm{c}) \mathrm{Al}^{3+}\left(c=3.0 \times 10^{-3}\right.$ $\mathrm{M})$ ions in $\mathrm{CH}_{3} \mathrm{CN}-\mathrm{H}_{2} \mathrm{O}(4: 1, \mathrm{v} / \mathrm{v}$, Tris $-\mathrm{HCl}$ buffer, $\mathrm{pH}=6.8)$ containing $1 \%$ DMF. [Inset: Emission intensity of 2 as a function of metal ion concentration and color change of the solutions during titration upon exposure to UV light].
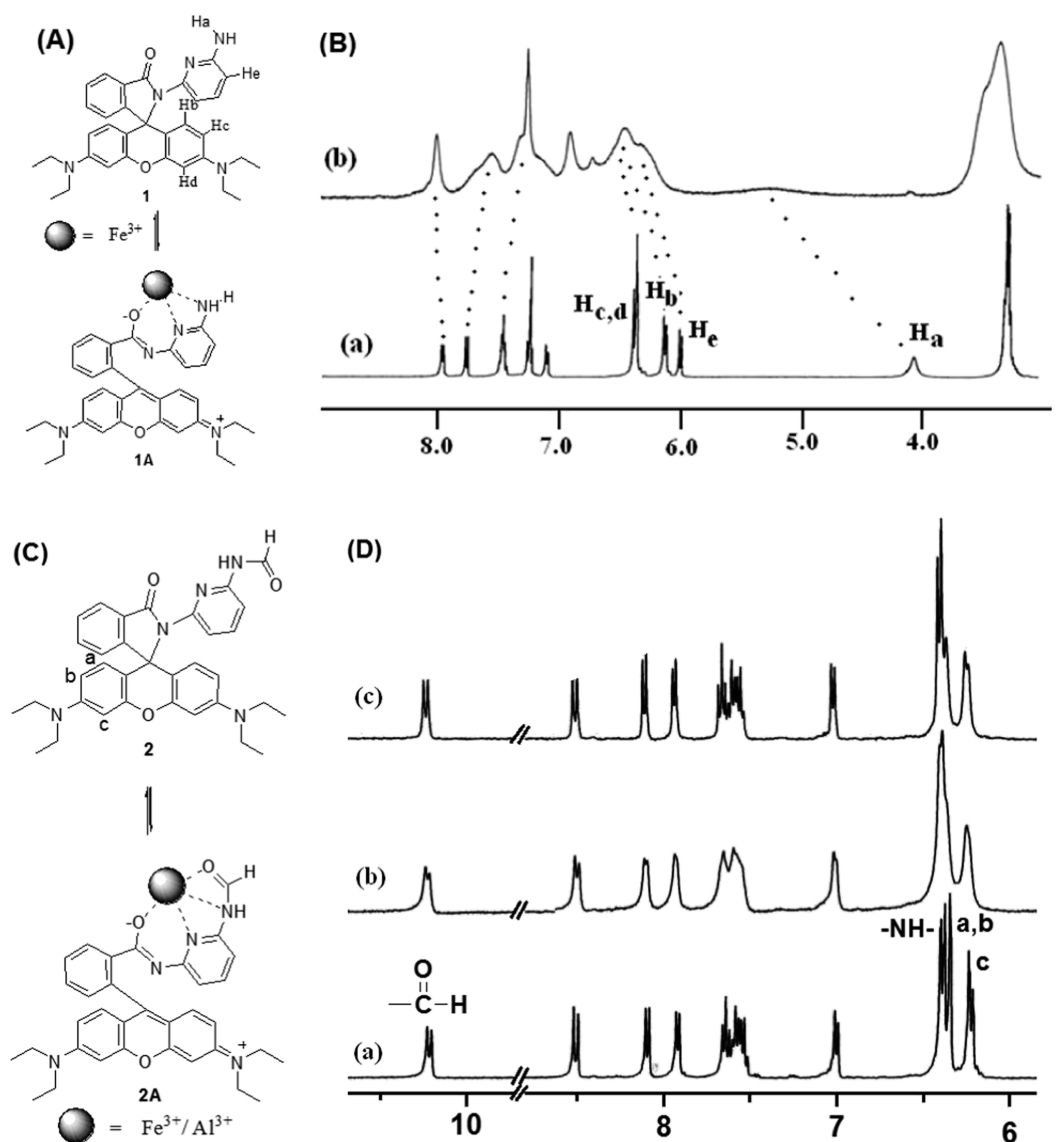

Figure 4. (A) Suggested mode of interaction of 1 with metal ions in solution. (B) Partial ${ }^{1} \mathrm{H}$ NMR $\left(400 \mathrm{MHz}, \mathrm{CDCl}_{3}\right)$ of (a) compound $\mathbf{1}$ (c $=$ $\left.1.97 \times 10^{-2} \mathrm{M}\right)$ and (b) 1 with the equiv. amount of $\mathrm{Fe}^{3+}$. (C) Suggested mode of interaction of 2 with metal ions in solution. (D) Partial ${ }^{1} \mathrm{H}$ NMR of (a) $2\left(c=5.49 \times 10^{-3} \mathrm{M}\right)$, (b) 2 with $\mathrm{Al}^{3+}(1: 1)$ and (c) 2 with $\mathrm{Fe}^{3+}(1: 1)$ in DMSO- $d_{6}$.

obvious changes in the emission spectra (Figures $3 \mathrm{a}$ and S5). In reference to $\mathbf{1}$, additional inclination of $\mathbf{2}$ for $\mathrm{Al}^{3+}$ is believed to be due to its $N$-formyl oxygen donor center. However, in comparison to $\mathbf{1}$, the emission of $\mathbf{2}$ at $585 \mathrm{~nm}$ was perturbed in almost equal extent and reached the plateau on gradual addition of only 10 equiv amounts of $\mathrm{Fe}^{3+}$ and $\mathrm{Al}^{3+}$ ions. Again, the nonfluorescent solutions became reddish brown in the presence of both $\mathrm{Fe}^{3+}$ and $\mathrm{Al}^{3+}$ ions under $\mathrm{UV}$ exposure (Figure 3b,c). 
The change in fluorescence response of 1 at $588 \mathrm{~nm}$ in the presence of other metal ions was also recorded, and data are cited in Figure S6, which corroborates its high selectivity and sensitivity toward $\mathrm{Fe}^{3+}$ ions. This experimental finding distinguishes the $\mathrm{Fe}^{3+}$ ion from the other metal ions studied. On the other hand, competitive experiments revealed mutual interference of $\mathrm{Fe}^{3+}$ and $\mathrm{Al}^{3+}$ ions for 2 in the detection process. The noninterfering nature of other metal ions as shown in Figure S7 indicates that compound $\mathbf{2}$ is able to sense both $\mathrm{Fe}^{3+}$ and $\mathrm{Al}^{3+}$ ions fluorimetrically over the other metal ions considered in the study with a high degree of selectivity and sensitivity. The distinction of these two metal ions was possible by $\mathrm{F}^{-}$ions as well as by their concentration variation as discussed later.

In the interaction, 1:1 stoichiometry of the $1-\mathrm{Fe}^{3+}$ complex was evaluated from the Benesi-Hildebrand plot $^{11}$ and the binding constant $\left(K_{\mathrm{a}}\right)$ for the formation of the $1-\mathrm{Fe}^{3+}$ complex was estimated to be $3.06 \times 10^{3} \mathrm{M}^{-1}$ (Figure S8). The detection limit ${ }^{2 \mathrm{e}}$ of $\mathbf{1}$ for $\mathrm{Fe}^{3+}$ was calculated to be $4.48 \times 10^{-6}$ M (Figure S9). Similarly, the linear nature of the plots of change in emission intensity against the reciprocal of concentration of metal ions suggests 1:1 stoichiometric complexes of 2 with $\mathrm{Fe}^{3+}$ and $\mathrm{Al}^{3+}$ ions with association constants of $7.85 \times 10^{3} \mathrm{M}^{-1}$ and $2.17 \times 10^{4} \mathrm{M}^{-1}$, respectively (Figure S10). Detection limits of 2 for $\mathrm{Fe}^{3+}$ were determined to be $2.79 \times 10^{-6} \mathrm{M}$ which is almost comparable to that of $\mathrm{Al}^{3+}$ $\left(2.43 \times 10^{-6} \mathrm{M}\right)$ (Figure S11). Comparison of the data indicates that a structural change from amine $\mathbf{1}$ to formamide $\mathbf{2}$ not only increase the metal-binding capability but also allows the lower limit of detection of the aforementioned metal ions.

To our opinion, the selective response of $\mathbf{1}$ toward the $\mathrm{Fe}^{3+}$ ion is ascribed to the strong participation of the binding center with the metal ion as shown in Figure 4A. In Fourier transform infrared (FTIR), the amide carbonyl stretching at $1698 \mathrm{~cm}^{-1}$ for the spirolactam moiety was changed into a lower wave number $1632 \mathrm{~cm}^{-1}$ in the presence of $\mathrm{Fe}^{3+}$ ions and thereby suggested the opening of the spiroring (Figure S12). Also, in ${ }^{1} \mathrm{H}$ NMR, the rhodamine ring protons of types $\mathrm{H}_{\mathrm{b}-\mathrm{d}}$ moved to the downfield direction with broadening in the presence of the equiv amount of $\mathrm{Fe}^{3+}$ ions (Figure 4B). Because of the interaction, the proton of the free amine (a-type) underwent a downfield chemical shift of $\sim 1 \mathrm{ppm}$ and became broad (paramagnetic effect of $\mathrm{Fe}^{3+}$ ). This suggested the involvement of the pyridine nitrogen in metal coordination.

Similarly, strong metal ion chelation into the binding cleft of $\mathbf{2}$ according to the mode suggested in Figure 4C is responsible for the generation of the xanthene moiety. As a result of this, in FTIR, the stretching frequencies of both $N$-formyl and amide carbonyls shifted to the lower regions by 3-8 and 23-24 $\mathrm{cm}^{-1}$, respectively, and became broad (Figure S13). Comparison of ${ }^{1} \mathrm{H}-\mathrm{NMR}$ spectra of $\mathbf{2}$ in the presence and absence of the equiv. amount of $\mathrm{Fe}^{3+}$ and $\mathrm{Al}^{3+}$ ions also supports this proposition. Almost similar changes were observed in the ${ }^{1} \mathrm{H}$ NMR. In both cases, strong metal-ligand interactions resulted in significant broadening of the formamide $-\mathrm{NHs}$. Moreover, a downfield chemical shift by $0.54 \mathrm{ppm}$ of the rhodamine ring protons $\left(\mathrm{H}_{\mathrm{a}-\mathrm{c}}\right)$ along with $0.28 \mathrm{ppm}$ downfield movement of the methylene protons strappingly corroborated the spiroring opening of $\mathbf{2}$ in the presence of $\mathrm{Fe}^{3+}$ and $\mathrm{Al}^{3+}$ ions, respectively (Figure 4D).

The ground-state interactions were understood by recording the changes in the UV-vis spectrum of $\mathbf{1}$ and $\mathbf{2}$ with the same metal ions in $\mathrm{CH}_{3} \mathrm{CN}-\mathrm{H}_{2} \mathrm{O}$. In $\mathrm{UV}-$ vis study, compound 1 initially showed strong absorption at 276 and $315 \mathrm{~nm}$. The intensities of these peaks were dramatically enhanced along with the manifestation of a new absorption at $559 \mathrm{~nm}$ in the presence of $\mathrm{Fe}^{3+}$ (Figure 5a). The growth of the absorption
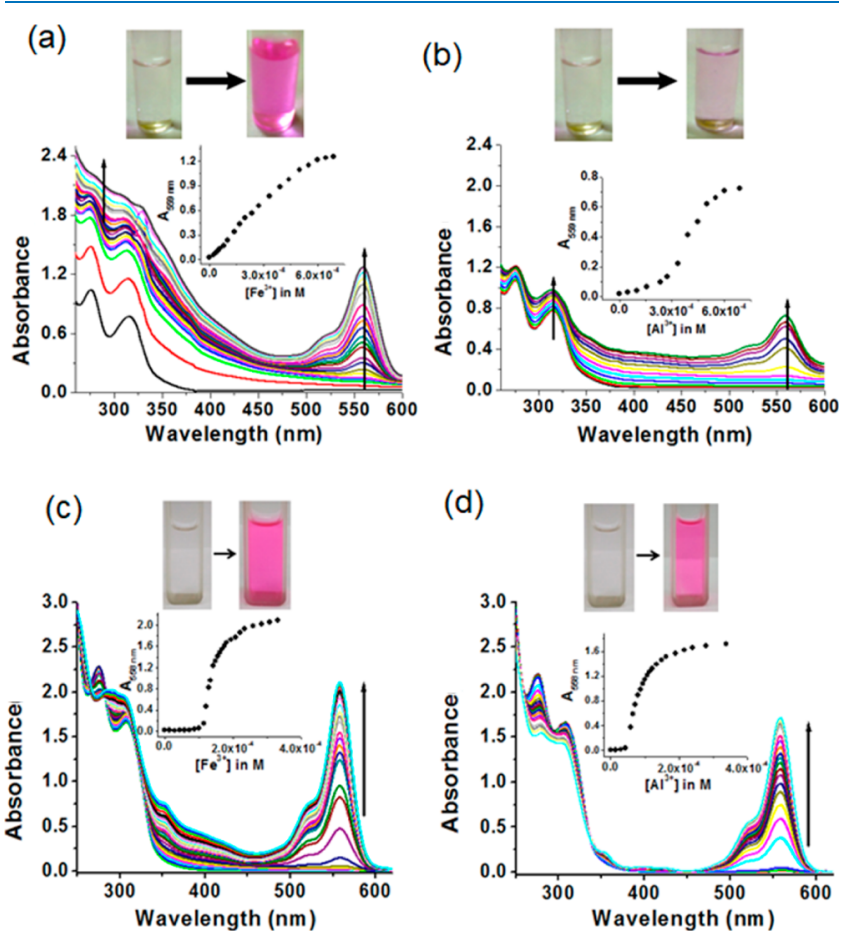

Figure 5. (a,b) Change in absorbance of $1\left(c=3.80 \times 10^{-5} \mathrm{M}\right)$ upon addition of 20 equiv amounts of (a) $\mathrm{Fe}^{3+}$ and (b) $\mathrm{Al}^{3+}\left(c=3.0 \times 10^{-3}\right.$ $\mathrm{M})$ in $\mathrm{CH}_{3} \mathrm{CN} /$ water $(4 / 1, \mathrm{v} / \mathrm{v} ; 10 \mu \mathrm{M}$ tris $\mathrm{HCl}$ buffer, $\mathrm{pH} 6.8)$. [Inset: Absorbance of $\mathbf{1}$ as a function of metal ion concentration and color change of the solutions during titration]. (c,d) Change in absorbance of $2\left(c=3.80 \times 10^{-5} \mathrm{M}\right)$ with 10 equiv amounts of $(\mathrm{c})$ $\mathrm{Fe}^{3+}$ and $(\mathrm{d}) \mathrm{Al}^{3+}\left(c=3.0 \times 10^{-3} \mathrm{M}\right)$ ions in $\mathrm{CH}_{3} \mathrm{CN}-\mathrm{H}_{2} \mathrm{O}(4: 1, \mathrm{v} / \mathrm{v}$, Tris $-\mathrm{HCl}$ buffer, $\mathrm{pH}=6.8$ ) containing 1\% DMF. [Inset: Absorbance of 2 as a function of metal ion concentration and color change of the solutions during titration].

peak at $559 \mathrm{~nm}$ is the consequence of spiroring opening in 1 that corresponds to the generation of the delocalized xanthene moiety in 1A. In the event, the colorless solution of 1 became pink in color. It is further mentionable that although the colorless solution of $\mathbf{1}$ became faint pink in color in the presence of $\mathrm{Al}^{3+}$ ions $\left(\varepsilon=1.91 \times 10^{4} \mathrm{M}^{-1} \mathrm{~cm}^{-1}\right)$ (Figure $5 \mathrm{~b}$ ), the response of the compound for this ion was considerably less than $\mathrm{Fe}^{3+}\left(\varepsilon=3.34 \times 10^{4} \mathrm{M}^{-1} \mathrm{~cm}^{-1}\right)$. This was not observed with other metal ions during the titration (Figure S14).

On the other hand, in case of $\mathbf{2}$, the strong absorptions at 274 and $308 \mathrm{~nm}$ were irregularly perturbed, and no characteristics changes were observed for all metal ions except $\mathrm{Fe}^{3+}$ and $\mathrm{Al}^{3+}$ ions (Figure $\left.\mathrm{S} 15\right)$. In the presence of $\mathrm{Fe}^{3+}(\varepsilon=$ $\left.5.51 \times 10^{4} \mathrm{M}^{-1} \mathrm{~cm}^{-1}\right)$ and $\mathrm{Al}^{3+}\left(\varepsilon=4.51 \times 10^{4} \mathrm{M}^{-1} \mathrm{~cm}^{-1}\right)$ ions, new absorption at $558 \mathrm{~nm}$ was again progressively intensified with a change in color of the solution from colorless to pink (Figure 5c,d). This corroborated that $\mathrm{Fe}^{3+}$ and $\mathrm{Al}^{3+}$ induced spirolactam ring opening in $\mathbf{2}$. Compound $\mathbf{2}$ remained silent in the titrations with other metal ions (Figure S16).

The reversible nature of metal complexation was tested by titrating the ensembles of $\mathbf{1}$ and $\mathbf{2}$ with $\mathrm{Fe}^{3+} / \mathrm{Al}^{3+}$ ions with different anions separately. Initially, the fluorescence and 

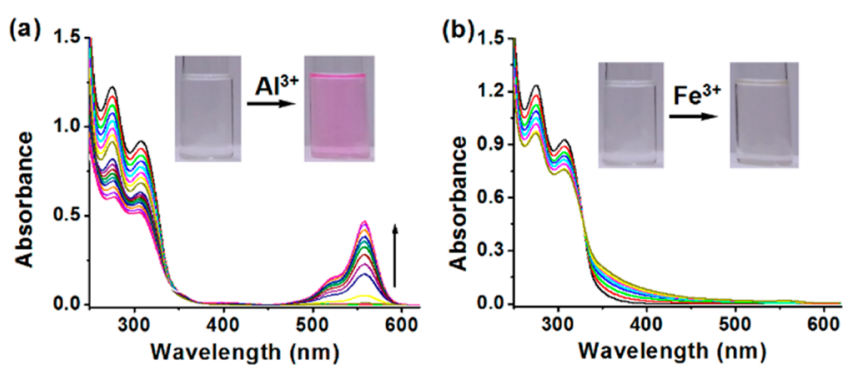

Figure 6. UV-vis titration spectra of $2\left(c=3.8 \times 10^{-5} \mathrm{M}\right)$ upon addition of 10 equiv. amounts of (a) $\mathrm{Al}^{3+}$ and (b) $\mathrm{Fe}^{3+}\left(c=5 \times 10^{-4}\right.$ $\mathrm{M})$ in $\mathrm{CH}_{3} \mathrm{CN} / \mathrm{H}_{2} \mathrm{O}(4: 1, \mathrm{v} / \mathrm{v} ; 10 \mathrm{mM}$ Tris- $\mathrm{HCl}$ buffer; $\mathrm{pH}=6.8)$. The insets show the color change of the solution.

absorption of the $\mathrm{Fe}^{3+}$ complex of $\mathbf{1}$ were studied with various anions in $\mathrm{CH}_{3} \mathrm{CN} /$ water. During fluorescence titration of the ensemble of $1-\mathrm{Fe}^{3+}$ with the anions such as $\mathrm{F}^{-}, \mathrm{OAc}^{-}$, and $\mathrm{H}_{2} \mathrm{PO}_{4}{ }^{-}$, the peak at $588 \mathrm{~nm}$ was progressively decreased and became labeled off (Figure S17). Under similar conditions, other anions brought moderate change in emission of the ensemble. The effect of anions on the decomplexation (characterized by the fading of the peak at $588 \mathrm{~nm}$ ) varied as $\mathrm{F}^{-} \approx \mathrm{OAc}^{-} \approx \mathrm{H}_{2} \mathrm{PO}_{4}^{-}>\mathrm{Cl}^{-} \approx \mathrm{Br}^{-} \approx \mathrm{I}^{-} \approx \mathrm{ClO}_{4}^{-}$. To our opinion, this order appears from strong interaction of more basic anions with the metal ion. ${ }^{5 a}$ A similar trend was noted in $\mathrm{UV}-$ vis titration. The absorption band at $559 \mathrm{~nm}$ vanished upon successive addition of $\mathrm{F}^{-}, \mathrm{OAc}^{-}$, and $\mathrm{H}_{2} \mathrm{PO}_{4}^{-}$ions and resulted in colorless solution (Figure S17). These findings pointed out the regeneration of the spiroring in the rhodamine part through the removal of the coordinated metal ion.

Similar experiments were carried out with the ensembles of 2 with $\mathrm{Fe}^{3+}$ and $\mathrm{Al}^{3+}$ ions. In fluorescence and $\mathrm{UV}$-vis, during titration with the $\mathrm{AcO}^{-}$ion, the peak at 585 and $558 \mathrm{~nm}$, respectively, became labeled off (Figures S18-S19). Interestingly, while $\mathrm{F}^{-}$brought a marked change in the optical properties of the $2-\mathrm{Fe}^{3+}$ ensemble, under identical conditions, moderate decrease in intensities of the peaks at $585,558 \mathrm{~nm}$ for the $2-\mathrm{Al}^{3+}$ ensemble in emission and absorption spectra, respectively, was observed (Figure S20). Thus, the $\mathrm{F}^{-}$ion is able to discriminate the $\mathrm{Fe}^{3+}$ and $\mathrm{Al}^{3+}$ complexes of 2 by exhibiting strong affinity for $\mathrm{Fe}^{3+}$ which in turn encouraged the demetallation process from the probe binding site. Rest of the anions undertaken showed a similar trend as that of $\mathbf{1}$ for both the ensembles (Figures S18-S19).

For compound 2, as we were not able to fully distinguish between $\mathrm{Al}^{3+}$ and $\mathrm{Fe}^{3+}$ ions by $\mathrm{F}^{-}$, we checked the complexation characteristics with variation of their concentrations. Importantly, successful distinction was achieved at low concentrations of $\mathrm{Al}^{3+}$ and $\mathrm{Fe}^{3+}$ ions. At concentration of $1 \times$ $10^{-4} \mathrm{M}$ of metal ions, compound 2 distinguished $\mathrm{Al}^{3+}$ from $\mathrm{Fe}^{3+}$ by showing different $\mathrm{UV}$-vis spectra as well as color of the solution of 2. Figure 6 explains this.

Metal-Ion Sensing in the Gel State. In contrast to $\mathbf{1}$, compound $\mathbf{2}$ was capable of forming self-assembled superstructures in the solvent of particular polarity. While the presence of most of the protic/polar solvents led to either precipitation or poor solubility, in toluene-hexane $(1: 1, \mathrm{v} / \mathrm{v})$, it exhibited instant gelation $(\mathrm{mgc}=12 \mathrm{mg} / \mathrm{mL})$. Under identical conditions, the nongelation behavior of 1 signified the key role of the formamide functionality in $\mathbf{2}$ that augments the selfaggregation by amplifying a number of intermolecular hydrogen bond contacts. Table S1 reports the gelation profiles of 1 and $\mathbf{2}$ in various solvents.

The gel of 2 obtained from toluene-hexane $(1: 1, \mathrm{v} / \mathrm{v})$ exhibited thermoreversible gel-sol phase transformation, and the gel melting temperature $\left(T_{\mathrm{g}}\right)$ increased linearly with the gelator's concentration (Figure S21). To understand the
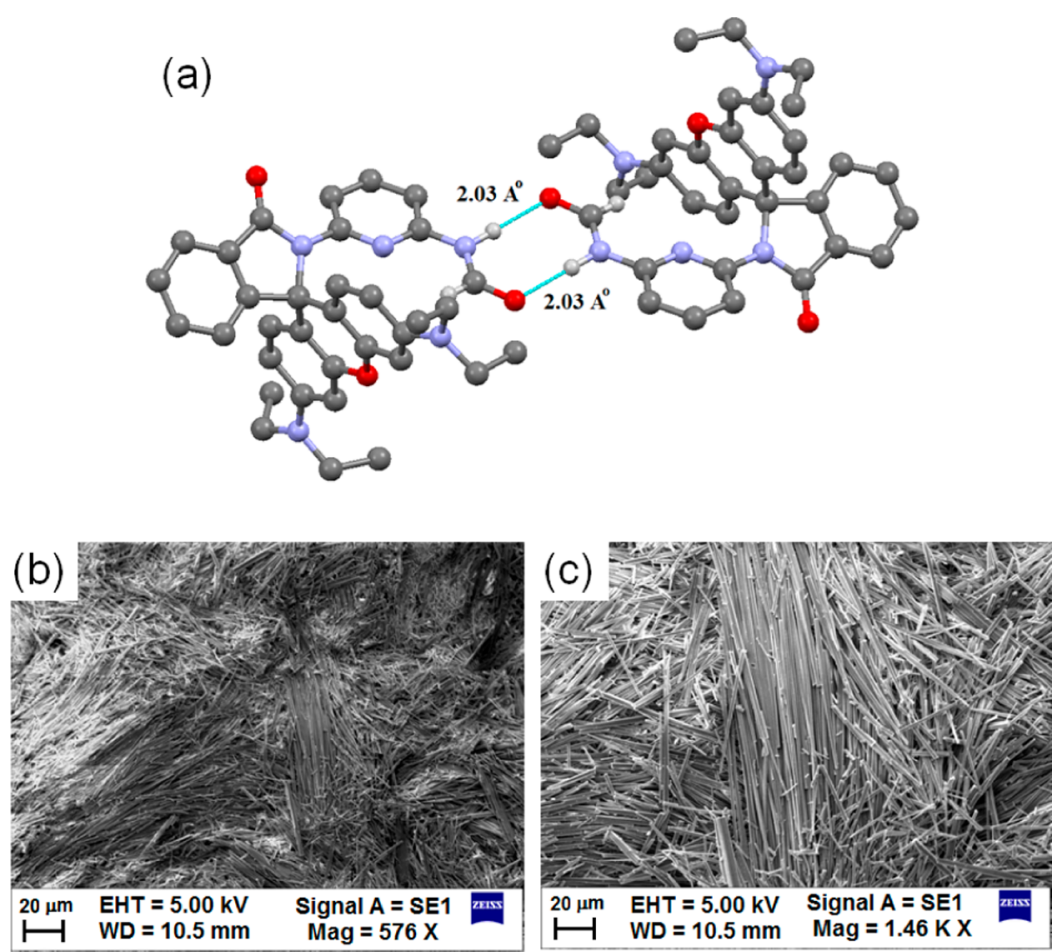

Figure 7. (a) Hydrogen-bonded dimer from single crystal X-ray; (b,c) SEM images of the xerogel of 2 obtained from the toluene-hexane (1:1, v/ v) solvent. 
hydrogen bond-mediated aggregation, FTIR spectra of 2 in amorphous and gel states were compared. Owing to hydrogen bonding, the stretching frequency of $\mathrm{N}$-formyl carbonyl was shifted to the lower region by $3 \mathrm{~cm}^{-1}$ in the gel state (Figure S22). Such hydrogen bonding features of the formamide motif are widely explored. ${ }^{12}$ In the present case, the engagement of formamide in the formation of the hydrogen-bonded dimer in the solid state is confirmed from packing of the crystal (Figure $7 \mathrm{a}$, Table S2). We believe that the rhodamine moiety with hydrophobic surfaces stabilizes the hydrogen-bonded network in the less polar solvent through hydrophobic-hydrophobic interaction. However, weak forces enable the gelator $\mathbf{2}$ to produce non-twisted rod-like fibers and fiber-bundles in the aggregated state, as evident from scanning electron microscopy (SEM) images (Figure $7 b, c)$.

After characterizing the gel, it was explored in metal-ion sensing. In this purpose, same metal ions as used earlier were undertaken and added as the solid on the top of the gel at room temperature. In presence of 2 equiv amounts of all metal ions, the gel state remained unaffected except $\mathrm{Ag}^{+}$which resulted in violet-colored sol formation within $2 \mathrm{~h}$ (Figure 8A).
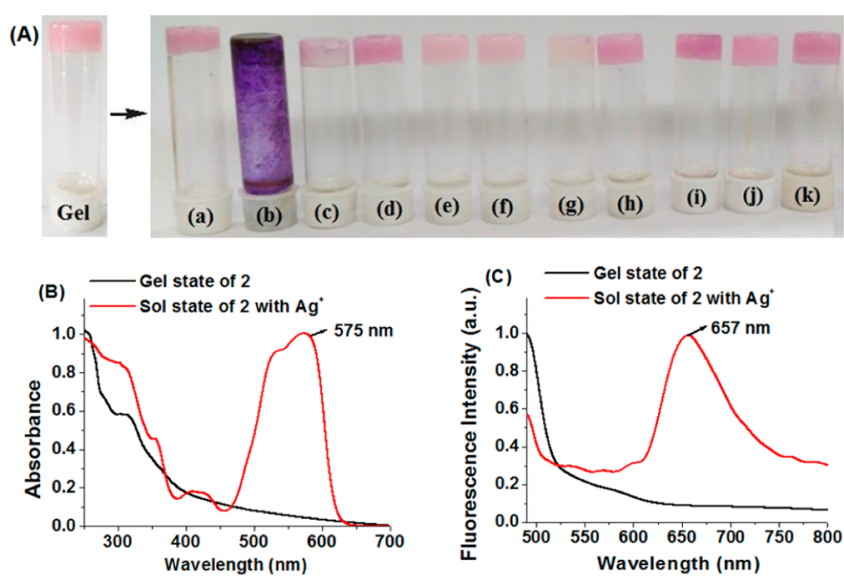

Figure 8. (A) Representation of the phase change of the toluenehexane $(1: 1, \mathrm{v} / \mathrm{v})$ gel of $2(12 \mathrm{mg} / \mathrm{mL})$ in the presence of 2 equiv amounts of (a) $\mathrm{Pb}^{2+}$, (b) $\mathrm{Ag}^{+}$, (c) $\mathrm{Cu}^{2+}$, (d) $\mathrm{Ni}^{2+}$, (e) $\mathrm{Zn}^{2+}$, (f) $\mathrm{Cd}^{2+}$, (g) $\mathrm{Fe}^{2+}$, (h) $\mathrm{Fe}^{3+}$, (i) $\mathrm{Al}^{3+},(\mathrm{j}) \mathrm{Co}^{2+}$, and (k) $\mathrm{Hg}^{2+}$ ions after $2 \mathrm{~h}$; normalized (B) UV-vis, and (C) emission spectra of 2 in sol and gel states.

The inability of other metal ions in bringing such gel-to-sol transition of 2 indicated the selectivity for $\mathrm{Ag}^{+}$ions. However, addition of tetrabutylammonium chloride to the $\mathrm{Ag}^{+}$ion containing sol did not cause reappearance of the gel. This is presumably due to poor solubility of the $2-\mathrm{Ag}^{+}$complex in the medium which prevents the demetallation reaction.

The $\mathrm{Ag}^{+}$-induced disruption of the gel was probably associated with the strong metal coordination involving the amide ion (obtained from spiroring opening) and pyridyl nitrogen atom ${ }^{13}$ that disturbed the intermolecular association of the molecules. A strong band at $575 \mathrm{~nm}$ in UV-vis of the broken gel established the spiroring opening (Figure $8 \mathrm{~B}$ ). In fluorescence, because of such spiroring opening, a strong emission at $657 \mathrm{~nm}$ was observed (Figure 8C). In FTIR, the stretching frequency of the amide carbonyl was shifted to a lower region by $24 \mathrm{~cm}^{-1}$ (Figure S23).

Cell Imaging. The utility of compounds $\mathbf{1}$ and $\mathbf{2}$ to detect $\mathrm{Fe}^{3+}$ and $\mathrm{Al}^{3+}$ ions in live cells was investigated through fluorescence. When A549 cells were treated with only $40 \mu \mathrm{M}$ of either compound $\mathbf{1}$ or compound $\mathbf{2}$ alone, they do not show any fluorescence under the microscope (Figures $9 \mathrm{~A}$ and
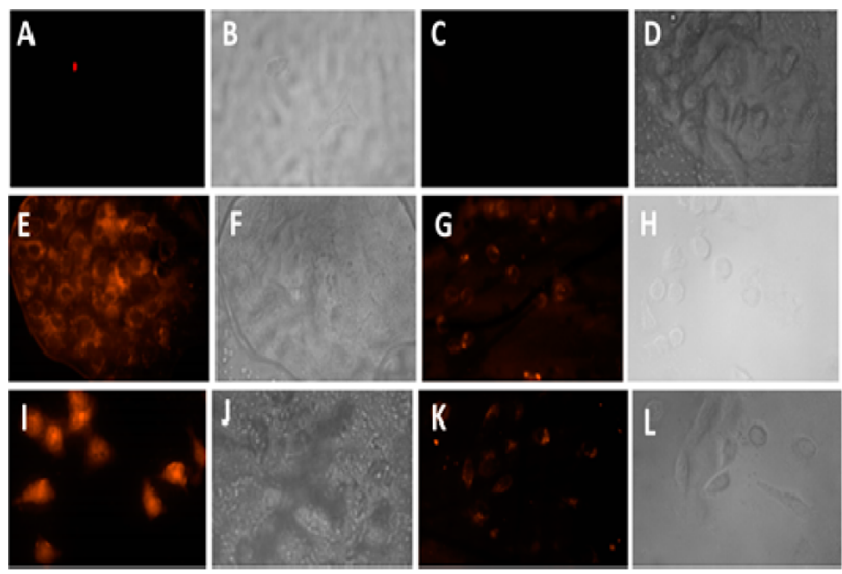

Figure 9. Fluorescence and bright field images of lung cancer cells (A549 cells): (A) fluorescence and (B) bright field images of cells treated with the probe $1(40 \mu \mathrm{M})$ for $24 \mathrm{~h}$ at $37^{\circ} \mathrm{C}$; (C) fluorescence and (D) bright field images of cells treated with acetonitrile; (E) fluorescence and $(\mathrm{F})$ bright field images of cells upon treatment with the probe $1(40 \mu \mathrm{M})$ and then with $\mathrm{Fe}\left(\mathrm{ClO}_{4}\right)_{3}(3 \mathrm{mM})$ for $24 \mathrm{~h}$ at 37 ${ }^{\circ} \mathrm{C}$; (G) fluorescence and $(\mathrm{H})$ bright field images of cells upon treatment with the probe $1(40 \mu \mathrm{M})$ and $\mathrm{Fe}\left(\mathrm{ClO}_{4}\right)_{3}(3 \mathrm{mM})$ and then with TBAF $(3 \mathrm{mM})$ for $24 \mathrm{~h}$ at $37^{\circ} \mathrm{C}$; (I) fluorescence and $(\mathrm{J})$ bright field images of cells upon treatment with the probe $1(40 \mu \mathrm{M})$ and then with $\mathrm{Al}\left(\mathrm{ClO}_{4}\right)_{3}(3 \mathrm{mM})$ for $24 \mathrm{~h}$ at $37^{\circ} \mathrm{C}$; $(\mathrm{K})$ fluorescence and $(\mathrm{L})$ bright field images of cells upon treatment with the probe 1 $(40 \mu \mathrm{M})$ and $\mathrm{Al}\left(\mathrm{ClO}_{4}\right)_{3}(3 \mathrm{mM})$ and then with $\mathrm{TBAF}(3 \mathrm{mM})$ for 24 $\mathrm{h}$ at $37^{\circ} \mathrm{C}$. All the colored pictures with the black background are photographed under the fluorescence microscope, and all the pictures are photographed under the normal light microscope.

S24A). When cells were incubated with $3 \mathrm{mM} \mathrm{Fe}^{3+}$ or $\mathrm{Al}^{3+}$ along with the compound $\mathbf{1}$ or $\mathbf{2}$, cells showed fluorescence. It appears from Figure 9E that compound $\mathbf{1}$ shows intense fluorescence with $\mathrm{Fe}^{3+}$ ions. This fluorescence was reduced to a significant extent when $3 \mathrm{mM} \mathrm{F}^{-}$ion was added (Figure 9G). The cells incubated individually with $3 \mathrm{mM} \mathrm{Fe}^{3+}$ and $\mathrm{Al}^{3+}$ along with compound $\mathbf{2}$ also exhibited fluorescence as shown in Figure S24.

Similarly, compounds $\mathbf{1}$ and $\mathbf{2}$ with $\mathrm{Al}^{3+}$ showed intense fluorescence as shown in Figures 9I and S24G, respectively. Notably, this fluorescence was reduced to the significant extent when the $3 \mathrm{mM} \mathrm{F}^{-}$ion was added further. For example, when $3 \mathrm{mM} \mathrm{F}^{-}$was added to compounds 1 and 2 with $\mathrm{Al}^{3+}$, the fluorescence was decreased as shown in Figures $9 \mathrm{~K}$ and S24I. No fluorescence in Figure 9C represents that the cells treated with acetonitrile only with the dose used for preparation of solutions of compounds used in these experiments. However, there is no effect of acetonitrile on cell viability within the dose used in our experiment. We used each compound up to 40 $\mu \mathrm{M}$, and cell viability was observed to be about 82 and $72 \%$ for compounds 1 and 2, respectively, at the dose (Figure S25).

\section{CONCLUSIONS}

In conclusion, 2,6-diaminopyridine-coupled rhodamine B derivatives $\mathbf{1}$ and $\mathbf{2}$ have been synthesized and the effect of substitution on amine functionality toward metal-ion interactions and self-assembly are thoroughly investigated. The compounds effectively recognized different metal ions of their 
biological significance in organic as well as in a semiaqueous system by exhibiting both color and fluorescence changes with a high degree of selectivity and sensitivity. Experimental findings reveal that the compound 1 which contains the amine group can be coupled to formyl functionality producing a new structure 2 to modulate the metal-ion selectivity under different conditions. While compound $\mathbf{1}$ is sensitive to $\mathrm{Fe}^{3+}$, compound 2 is responsive to $\mathrm{Fe}^{3+}$ as well as $\mathrm{Al}^{3+}$ ions in the aqueous $\mathrm{CH}_{3} \mathrm{CN}$ medium with a higher association constant. The distinction of the $\mathrm{Fe}^{3+}$ ion form $\mathrm{Al}^{3+}$ has been possible by $\mathrm{F}^{-}$as a chelating ion as well as by concentration variation of the metal ions. Compounds are cell permeable and capable to detect the mentioned metal ions in human lung cancer cells (a549).

Moreover, unlike 1, compound $\mathbf{2}$ forms a faint pink gel from the toluene-hexane $(1: 1, \mathrm{v} / \mathrm{v})$ mixture solvent. Experimental observations establish the role of the formamide moiety in 2 that augments the self-aggregation by amplifying the number of intermolecular hydrogen bond contacts compared to $\mathbf{1}$. The gel is metal ion responsive and selectively recognizes $\mathrm{Ag}^{+}$ions by exhibiting violet-colored sol formation. Thus, the selectivity and sensitivity can easily be altered by the incorporation of different functionalities on the $-\mathrm{NH}_{2}$ group of $\mathbf{1}$. There are reasonable numbers of silver responsive gelators found in the literature (Table S3). Importantly, the gel phase sensing of metal ions by rhodamine derivatives is completely unknown, and therefore, compound $\mathbf{2}$ draws attention, in this regard.

\section{EXPERIMENTAL SECTION}

Materials and Methods. 2,6-Diaminopyridine, rhodamine $\mathrm{B}, \mathrm{POCl}_{3}$, and ammonium formate were procured from Spectrochem. Metal perchlorates in the study were obtained from Sigma-Aldrich and were handled with care. All solvents as used in the synthesis were properly dried and distilled before use. Solvents for NMR experiments were procured from Aldrich. Thin layer chromatography was done on Merck precoated silica gel 60 - F254 plates. ${ }^{1} \mathrm{H}$ and ${ }^{13} \mathrm{C}$ NMR spectra were recorded on a Bruker $400 \mathrm{MHz}$ instrument. Highresolution mass data were obtained from an XEVO GS-2 QTOf Waters mass spectrometer using the electron spray ionization technique. FTIR measurements of the compounds were on a PerkinElmer L120-00A spectrometer $\left(\nu_{\max }\right.$ in $\left.\mathrm{cm}^{-1}\right)$ using $\mathrm{KBr}$ pellets. Fluorescence and UV-vis are studied using a PerkinElmer spectrofluorimeter (LS55) and Shimadzu UV2450 spectrophotometer, respectively. SEM images were obtained on the EVO LS-10 ZEISS instrument.

Synthesis. Compound $1 .^{5 a}$ Rhodamine B (0.5 g, 1.12 mmol) was taken in 1,2-dichloroethane $(20 \mathrm{~mL})$ and stirred for $20 \mathrm{~min}$. Then, $\mathrm{POCl}_{3}(0.21 \mathrm{~mL}, 2.24 \mathrm{mmol})$ was added to this stirred solution. The reaction mixture was heated under reflux for $2 \mathrm{~h}$. The mixture was cooled. and excess $\mathrm{POCl}_{3}$ was evaporated under reduced pressure to have compound 3 as a solid mass, which was used directly in the next step without purification. Compound 3 was dissolved in dry $\mathrm{CH}_{2} \mathrm{Cl}_{2}(30$ $\mathrm{mL})$, and to this, a solution of 2,6-diaminopyridine (0.49 $\mathrm{g}$, $4.48 \mathrm{mmol})$ containing $\mathrm{Et}_{3} \mathrm{~N}(0.25 \mathrm{~mL}, 1.7 \mathrm{mmol})$ was added. The mixture was stirred for $10 \mathrm{~h}$ at room temperature, and the completion of reaction was verified by thin layer chromatography. Finally, the solvent was removed, and water was added. The mixture was extracted with ethyl acetate. The organic layer was collected and dried over anhydrous sodium sulphate. Evaporation of ethyl acetate gave a crude mass which was next purified by column chromatography using $40 \%$ ethyl acetate in petroleum ether to give a pure compound $1(0.72 \mathrm{~g})$ in $58 \%$ yield. Mp $208{ }^{\circ} \mathrm{C},{ }^{1} \mathrm{H}$ NMR $\left(\mathrm{CDCl}_{3}, 400 \mathrm{MHz}\right): \delta 7.98$ (d, $1 \mathrm{H}, J=8 \mathrm{~Hz}), 7.78(\mathrm{~d}, 1 \mathrm{H}, J=8 \mathrm{~Hz}), 7.50-7.47(\mathrm{~m}, 2 \mathrm{H})$, $7.29-7.26(\mathrm{~m}, 1 \mathrm{H}), 7.13(\mathrm{~d}, 1 \mathrm{H}, J=8 \mathrm{~Hz}), 6.40-6.37(\mathrm{~m}$, $4 \mathrm{H}), 6.13\left(\mathrm{dd}, 2 \mathrm{H}, J_{1}=8 \mathrm{~Hz}, J_{2}=4 \mathrm{~Hz}\right), 6.01(\mathrm{~d}, 1 \mathrm{H}, J=8$ $\mathrm{Hz}), 4.06(\mathrm{~s}, 2 \mathrm{H}), 3.32-3.27(\mathrm{~m}, 8 \mathrm{H}), 1.13(\mathrm{t}, 12 \mathrm{H}, J=8 \mathrm{~Hz})$; ${ }^{13} \mathrm{C}$ NMR $\left(\mathrm{CDCl}_{3}, 100 \mathrm{MHz}\right): \delta 167.9,156.0,153.9,153.4$, $149.1,148.3,138.5,133.3,131.1,128.1,124.4,123.0,109.1$, $107.0,104.9,103.2,97.2,66.1,44.2,12.6$ (one carbon in the aromatic region is unresolved); FTIR $(\mathrm{KBr}) \nu \mathrm{cm}^{-1}$ : 3498 , 2967, 2853, 1699, 1634, 1514, 1444, 1221; Mass (EI): 534.0 $(\mathrm{M}+1)^{+}$.

Compound 2. To a stirred solution of compound 1 (500 $\mathrm{mg}, 0.94 \mathrm{mmol})$ in dry acetonitrile $(10 \mathrm{~mL})$, anhydrous ammonium formate $(120 \mathrm{mg}, 1.90 \mathrm{mmol})$ was added, and the resulting mixture was heated to reflux at $95{ }^{\circ} \mathrm{C}$ (bath temperature) for $10 \mathrm{~h}$. After removal of acetonitrile under reduced pressure, a residue was diluted with ethyl acetate (40 $\mathrm{mL})$ and washed with water $(2 \times 20 \mathrm{~mL})$. The organic layer was separated, dried over anhydrous $\mathrm{Na}_{2} \mathrm{SO}_{4}$, and then concentrated under reduced pressure to afford the pure compound $2(269 \mathrm{mg}, 51 \%)$ as a white solid, mp $232{ }^{\circ} \mathrm{C} .{ }^{1} \mathrm{H}$ NMR (DMSO- $\left.d_{6}, 400 \mathrm{MHz}\right): \delta 10.21(\mathrm{~d}, 1 \mathrm{H}, J=8 \mathrm{~Hz}), 8.50$ $(\mathrm{d}, 1 \mathrm{H}, J=8 \mathrm{~Hz}), 8.09(\mathrm{~d}, 1 \mathrm{H}, J=8 \mathrm{~Hz}), 7.91(\mathrm{~d}, 1 \mathrm{H}, J=8$ $\mathrm{Hz}), 7.64(\mathrm{t}, 1 \mathrm{H}, J=8 \mathrm{~Hz}), 7.60-7.51(\mathrm{~m}, 2 \mathrm{H}), 7.00(\mathrm{~d}, 1 \mathrm{H}, J$ $=8 \mathrm{~Hz}), 6.40-6.37(\mathrm{~m}, 3 \mathrm{H}), 6.34(\mathrm{~s}, 2 \mathrm{H}), 6.23-6.21(\mathrm{~m}$, $2 \mathrm{H}), 3.33-3.19(\mathrm{~m}, 8 \mathrm{H}), 1.05(\mathrm{t}, 12 \mathrm{H}, \mathrm{J}=8 \mathrm{~Hz}) ;{ }^{13} \mathrm{C} \mathrm{NMR}$ $\left(\mathrm{DMSO}_{6}, 100 \mathrm{MHz}\right): \delta 168.1,163.0,154.3,152.1,149.8$, $149.3,148.3,140.1,134.6,128.9,128.7,127.5,124.3,123.5$, 111.0, 108.0, 107.9, 106.7, 97.5, 65.7, 44.1, 12.7; FTIR (KBr) $\nu$ $\mathrm{cm}^{-1}: 3279,2972,2929,1701,1670,1617$; HRMS (TOF MS $\left.\mathrm{ES}^{+}\right)$: calcd $534.2864(\mathrm{M}-\mathrm{CO}+\mathrm{H})^{+}$; found, $534.2852(\mathrm{M}-$ $\mathrm{CO}+\mathrm{H})^{+}$.

General Procedures for Fluorescence and UV-Vis Titrations. Stock solutions of the compounds were prepared in the desired solvent in a concentration of $3.80 \times 10^{-5} \mathrm{M}$. Stock solutions of metal ions were in the same solvent in a concentration of $3.0 \times 10^{-3} \mathrm{M}$. Working solution of each compound $(2 \mathrm{~mL})$ was placed in the cuvette. Stock solutions of different metal ions were added in different amounts. Upon adding metal ions, the change in emission of the compound was recorded. The same stock solutions were used in the similar way in UV-vis titrations.

Binding Constant Determination. ${ }^{11}$ The binding constant $\left(K_{\mathrm{a}}\right)$ was determined by the Benesi-Hildebrand plot using the expression: $I_{0} / \Delta I=\left[\varepsilon_{\mathrm{M}} /\left(\varepsilon_{\mathrm{M}}-\varepsilon_{\mathrm{C}}\right)\right]\left(K_{\mathrm{a}}^{-1} C_{\mathrm{g}}^{-1}+1\right)$, where $\varepsilon_{\mathrm{M}}$ and $\varepsilon_{\mathrm{C}}$ are molar extinction coefficients of the compound and the complex, respectively, at a selected wavelength; $I_{0}$ represents the emission intensity of free compounds at that specific wavelength, and $C_{\mathrm{g}}$ is the concentration of the metal ions. The linear fit of $I_{0} / \Delta I$ with the inverse of the metal ion concentration indicated 1:1 stoichiometry of the complex. The ratio of the intercept to slope was used for binding constant $\left(K_{\mathrm{a}}\right)$ determination.

Calculation of the Detection Limit. ${ }^{2 e}$ The detection limit was determined using the fluorescence titration data. The emissions of 1 and 2 at 588 and $585 \mathrm{~nm}$, respectively, was measured six times to achieve the standard deviation of blank measurement. The fluorescence intensities at 588 and $585 \mathrm{~nm}$ for $\mathbf{1}$ and 2, respectively, were plotted against concentrations of metal ions to determine the slope. Then, detection limits were calculated using the equation: Detection limit $=3 \sigma / k$, where $\sigma$ 
and $k$ refer the standard deviation of blank measurement and the slope, respectively.

Gelation Test. The necessary amount of compound 2 was taken in a solvent $(1 \mathrm{~mL})$ of choice and slightly warmed to make a homogeneous solution. Gel formation which was checked via the usual inversion of the vial method occurred when the temperature of the undisturbed solution reached to room temperature. For SEM imaging, the sample of the gel was dried under vacuum, and then, it was coated with a thin layer of gold metal.

Method of Determination of Gel-Sol Transition Temperature. The gel transition temperature $\left(T_{\mathrm{g}}\right)$ at which gel is melted and started to flow was measured by the dropping ball method. In this method, a small glass ball was placed on the top of the gel taken in a test tube. The tube was then slowly heated in a thermostated oil bath. The temperature at which the ball fell and reached the bottom of the test tube was assigned as $T_{\mathrm{g}}$ of the gel.

Cell Culture. A549 cell was purchased from the National Centre for Cell Sciences, Pune, India. Cells were cultured in the Dulbecco's modified Eagle's medium media supplemented with $10 \%$ fetal bovine serum at $37{ }^{\circ} \mathrm{C}$ under humidified conditions containing $5 \% \mathrm{CO}_{2}$.

Cellular Uptake. About 50,000 cells were grown on a cover slip in each well of a 24-well plate. After overnight incubation, media were discarded and washed with $1 \mathrm{X}$ PBS. Then, cells were incubated with appropriate concentration of the compounds 1 and 2 with or without $\mathrm{Al}^{3+}, \mathrm{Fe}^{3+}$, and $\mathrm{F}^{-}$. We took $40 \mu \mathrm{M}$ of compounds 1 and 2 with or without $3 \mathrm{mM}$ of $\mathrm{Al}^{3+}, \mathrm{Fe}^{3+}$, and $\mathrm{F}^{-}$. Then, those cover slips were placed on a clean grease-free glass slide upside down. Cell images were captured under 40× magnification of AxioscopeA1 (Carl Zeiss) fluorescence microscope.

Cell Viability by Trypan Bue Method. About $10^{5}$ A549 cells were plated in each $35 \mathrm{~mm}$ plates. Cells were then treated with different concentrations of compounds 1 and $2(10 \mu \mathrm{M}, 20$ $\mu \mathrm{M}$ and $40 \mu \mathrm{M})$. After $24 \mathrm{~h}$, treatment cells were incubated with $0.2 \%$ of Trypan blue. Then, cells were counted with a hemocytometer chamber under a light microscope.

\section{ASSOCIATED CONTENT}

\section{SI Supporting Information}

The Supporting Information is available free of charge at https://pubs.acs.org/doi/10.1021/acsomega.0c01384.

Emission and absorption spectra, change of fluorescence, Benesi-Hildebrand plot, binding curves, detection limit, NMR and mass studies, pictorial representations, cell viabilities, copies of ${ }^{1} \mathrm{H},{ }^{13} \mathrm{C}$ NMR, FTIR and HRMS spectra (PDF)

\section{AUTHOR INFORMATION}

\section{Corresponding Author}

Kumaresh Ghosh - Department of Chemistry, University of Kalyani, Kalyani 741235, India; 이이이.org/0000-0003-

1236-8139; Email: ghosh_k2003@yahoo.co.in, kumareshchem18@klyuniv.ac.in

\section{Authors}

Santanu Panja - Department of Chemistry, University of Kalyani, Kalyani 741235, India; School of Chemistry, University of Glasgow, Glasgow G12 8QQ, U.K.
Subhendu Mondal - Department of Chemistry, University of Kalyani, Kalyani 741235, India

Sourav Ghosh - Department of Biochemistry and Biophysics, University of Kalyani, Kalyani 741235, India

Utpal Ghosh - Department of Biochemistry and Biophysics, University of Kalyani, Kalyani 741235, India

Complete contact information is available at:

https://pubs.acs.org/10.1021/acsomega.0c01384

\section{Notes}

The authors declare no competing financial interest.

\section{ACKNOWLEDGMENTS}

S.P. thanks the Royal Society and SERB of India for a Newton International Fellowship. S.M. thanks UGC, New Delhi, India for fellowship. K.G. thanks SERB, DST, New Delhi, for financial support (file no. EMR/2016/008005/OC). We also acknowledge the kind help of Dr. Constantin Gabriel Daniliuc, Organisch-Chemisches Institut Universität, Münster Corrensstrasse 40 D-48149 Münster for solving the crystal data.

\section{REFERENCES}

(1) (a) Spichiger-Keller; Ursula, E. Appendix 7. Chemical Sensors and Biosensors for Medical and Biological Applications; John Wiley \& Sons, 2008; pp 373-375. (b) Qian, X.; Xu, Z. Fluorescence imaging of metal ions implicated in diseases. Chem. Soc. Rev. 2015, 44, 44874493. (c) Anichini, C.; Czepa, W.; Pakulski, D.; Aliprandi, A.; Ciesielski, A.; Samorì, P. Chemical sensing with 2D materials. Chem. Soc. Rev. 2018, 47, 4860-4908. (d) Zhang, Q.; Wang, C.-F.; Lv, Y.-K. Luminescent switch sensors for the detection of biomolecules based on metal-organic frameworks. Analyst 2018, 143, 4221-4229. (e) Wood, E. J. Molecular probes: Handbook of fluorescent probes and research chemicals: By R P Haugland. pp 390. Interchim (Molecular Probes Inc, PO Box 22010 Eugene, OR 97402-0414, USA, or 15 rue des Champs, 92600 Asnieres, Paris). 1992-1994. \$15. Biochem. Educ. 1994, 22, 83.

(2) (a) Panja, S.; Chattopadhyay, A. P.; Ghosh, K. Naphthalene and pyrrole substituted guanidine in selective sensing of $\mathrm{Cu}^{2+}, \mathrm{Hg}^{2+}, \mathrm{Pb}^{2+}$ and $\mathrm{CN}^{-}$ions under different conditions. Supramol. Chem. 2017, 29, 528-535. (b) Lee, M. H.; Kim, J. S.; Sessler, J. L. Small moleculebased ratiometric fluorescence probes for cations, anions, and biomolecules. Chem. Soc. Rev. 2015, 44, 4185-4191. (c) Lustig, W. P.; Mukherjee, S.; Rudd, N. D.; Desai, A. V.; Li, J.; Ghosh, S. K. Metal-organic frameworks: functional luminescent and photonic materials for sensing applications. Chem. Soc. Rev. 2017, 46, 32423285. (d) Li, J.; Yim, D.; Jang, W.-D.; Yoon, J. Recent progress in the design and applications of fluorescence probes containing crown ethers. Chem. Soc. Rev. 2017, 46, 2437-2458. (e) Panja, S.; Debnath, S.; Ghosh, K. Fluorophore inserted bisbenzimidazole clefts in selective sensing of $\mathrm{Ag}+$ and $\mathrm{Cu}^{2+}$ ions. J. Photochem. Photobiol., A 2017, 348, 110-117. (f) Li, Z.; Askim, J. R.; Suslick, K. S. The Optoelectronic Nose: Colorimetric and Fluorometric Sensor Arrays. Chem. Rev. 2019, 119, 231-292. (g) Xiao, M.; Lai, W.; Man, T.; Chang, B.; Li, L.; Chandrasekaran, A. R.; Pei, H. Rationally Engineered Nucleic Acid Architectures for Biosensing Applications. Chem. Rev. 2019, 119, 11631-11717. (h) Cao, D.; Liu, Z.; Verwilst, P.; Koo, S.; Jangjili, P.; Kim, J. S.; Lin, W. Coumarin-Based Small-Molecule Fluorescent Chemosensors. Chem. Rev. 2019, 119, 10403-10519.

(3) (a) Chen, L.; Wu, D.; Yoon, J. Recent Advances in the Development of Chromophore-Based Chemosensors for Nerve Agents and Phosgene. ACS Sens. 2018, 3, 27-43. (b) Saleem, M.; Lee, K. H. Optical sensor: a promising strategy for environmental and biomedical monitoring of ionic species. RSC Adv. 2015, 5, 7215072287. (c) Kaur, N.; Chopra, S.; Singh, G.; Raj, P.; Bhasin, A.; Sahoo, S. K.; Kuwar, A.; Singh, N. Chemosensors for biogenic amines and biothiols. J. Mater. Chem. B 2018, 6, 4872-4902. (d) Sarkar, A.; 
Bhattacharyya, S.; Mukherjee, A. Colorimetric detection of fluoride ions by anthraimidazoledione based sensors in the presence of $\mathrm{Cu}(\mathrm{II})$ ions. Dalton Trans. 2016, 45, 1166-1175. (e) Yan, Z.; Yuen, M.-F.; $\mathrm{Hu}, \mathrm{L}$.; Sun, P.; Lee, C.-S. Advances for the colorimetric detection of $\mathrm{Hg}^{2+}$ in aqueous solution. RSC Adv. 2014, 4, 48373-48388. (f) Praveen Kumar, P. P.; Kathuria, L.; Haridas, V. Cysteine-based silver nanoparticles as dual colorimetric sensors for cations and anions. New J. Chem. 2016, 40, 8382-8389. (g) Zhou, Y.; Zhang, J. F.; Yoon, J. Fluorescence and Colorimetric Chemosensors for Fluoride-Ion Detection. Chem. Rev. 2014, 114, 5511-5571. (h) Karami, C.; Mehr, S. Y.; Deymehkar, E.; Taher, M. A. Naked Eye Detection of $\mathrm{Cr}^{3+}$ and $\mathrm{Co}^{2+}$ Ions by Gold Nanoparticle Modified with Azomethine. Plasmonics 2018, 13, 537-544. (i) Salimi, F.; Kiani, M.; Karami, C.; Taher, M. A. Colorimetric sensor of detection of $\mathrm{Cr}$ (III) and $\mathrm{Fe}$ (II) ions in aqueous solutions using gold nanoparticles modified with methylene blue. Optik 2018, 158, 813-825.

(4) (a) Anila, H. A.; Ali, F.; Das, A., 8.15 - Specific Receptors and Imaging Reagents for Certain Heavy Metal Toxins. In Comprehensive Supramolecular Chemistry II; Atwood, J. L., Ed.; Elsevier: Oxford, 2017; pp 319-349. (b) Mahato, P.; Saha, S.; Das, P.; Agarwalla, H.; Das, A. An overview of the recent developments on $\mathrm{Hg}^{2+}$ recognition. RSC Adv. 2014, 4, 36140-36174. (c) Reddy G, U.; Lo, R.; Roy, S.; Banerjee, T.; Ganguly, B.; Das, A. A new receptor with a FRET based fluorescence response for selective recognition of fumaric and maleic acids in aqueous medium. Chem. Commun. 2013, 49, 9818-9820. (d) Agarwalla, H.; Mahajan, P. S.; Sahu, D.; Taye, N.; Ganguly, B.; Mhaske, S. B.; Chattopadhyay, S.; Das, A. A Switch-On NIR Probe for Specific Detection of $\mathrm{Hg}^{2+}$ Ion in Aqueous Medium and in Mitochondria. Inorg. Chem. 2016, 55, 12052-12060. (e) Maity, A.; Ali, F.; Agarwalla, H.; Anothumakkool, B.; Das, A. Tuning of multiple luminescence outputs and white-light emission from a single gelator molecule through an ESIPT coupled AIEE process. Chem. Commun. 2015, 51, 2130-2133.

(5) (a) Ghosh, K.; Panja, S.; Sarkar, T. Rhodamine-linked pyridyl thiourea as a receptor for selective recognition of $\mathrm{F}^{-}, \mathrm{Al}^{3+}$ and $\mathrm{Ag}^{+}$ under different conditions. Supramol. Chem. 2015, 27, 490-500. (b) Culzoni, M. J.; de la Peña, A. M.; Machuca, A.; Goicoechea, H. C.; Babiano, R. Rhodamine and BODIPY chemodosimeters and chemosensors for the detection of $\mathrm{Hg}^{2+}$, based on fluorescence enhancement effects. Anal. Methods 2013, 5, 30-49. (c) Zhang, Y.; Zeng, X.; Mu, L.; Chen, Y.; Zhang, J.-X.; Redshaw, C.; Wei, G. Rhodamine-triazine based probes for $\mathrm{Cu} 2+$ in aqueous media and living cells. Sens. Actuators, B 2014, 204, 24-30. (d) Yang, Y.; Gao, C.-Y.; Liu, J.; Dong, D. Recent developments in rhodamine salicylidene hydrazone chemosensors. Anal. Methods 2016, 8, 2863-2871. (e) Chen, X.; Pradhan, T.; Wang, F.; Kim, J. S.; Yoon, J. Fluorescent Chemosensors Based on Spiroring-Opening of Xanthenes and Related Derivatives. Chem. Rev. 2012, 112, 19101956.

(6) (a) Reddy G, U.; A, A. H.; Taye, N.; Chattopadhyay, S.; Das, A. FRET-Based Probe for Monitoring $\mathrm{pH}$ Changes in Lipid-Dense Region of Hct116 Cells. Org. Lett. 2015, 17, 5532-5535. (b) Reddy G, U.; Ali, F.; Taye, N.; Chattopadhyay, S.; Das, A. A new turn on $\mathrm{Pd}^{2+}$-specific fluorescence probe and its use as an imaging reagent for cellular uptake in Hct116 cells. Chem. Commun. 2015, 51, 36493652. (c) Ali, F.; Saha, S.; Maity, A.; Taye, N.; Si, M. K.; Suresh, E.; Ganguly, B.; Chattopadhyay, S.; Das, A. Specific Reagent for Cr(III): Imaging Cellular Uptake of $\mathrm{Cr}(\mathrm{III})$ in Hct116 Cells and Theoretical Rationalization. J. Phys. Chem. B 2015, 119, 13018-13026. (d) Saha, S.; Mahato, P.; Baidya, M.; Ghosh, S. K.; Das, A. An interrupted PET coupled TBET process for the design of a specific receptor for $\mathrm{Hg} 2+$ and its intracellular detection in MCF7 cells. Chem. Commun. 2012, 48, 9293-9295. (e) Mahato, P.; Saha, S.; Suresh, E.; Di Liddo, R.; Parnigotto, P. P.; Conconi, M. T.; Kesharwani, M. K.; Ganguly, B.; Das, A. Ratiometric Detection of $\mathrm{Cr}^{3+}$ and $\mathrm{Hg}^{2+}$ by a NaphthalimideRhodamine Based Fluorescent Prober. Inorg. Chem. 2012, 51, 17691777.

(7) (a) Miravet, J. F.; Escuder, B. Molecular Gels as Containers for Molecular Recognition, Reactivity and Catalysis. Functional Molecular
Gels; The Royal Society of Chemistry, 2014; Chapter 5, pp 117-156. (b) Segarra-Maset, M. D.; Nebot, V. J.; Miravet, J. F.; Escuder, B. Control of molecular gelation by chemical stimuli. Chem. Soc. Rev. 2013, 42, 7086-7098. (c) Panja, A.; Ghosh, S.; Ghosh, K. A sulfonyl hydrazone cholesterol conjugate: gelation, anion interaction and its application in dye adsorption. New J. Chem. 2019, 43, 10270-10277. (d) Liu, M.; Ouyang, G.; Niu, D.; Sang, Y. Supramolecular gelatons: towards the design of molecular gels. Org. Chem. Front. 2018, 5, 2885-2900. (e) Panja, A.; Ghosh, K. Cholesterol-based diazine derivative: selective sensing of $\mathrm{Ag}^{+}$and $\mathrm{Fe}^{3+}$ ions through gelation and the performance of metallogels in dye and picric acid adsorption from water. Mater. Chem. Front. 2018, 2, 2286-2296. (f) Amabilino, D. B.; Smith, D. K.; Steed, J. W. Supramolecular materials. Chem. Soc. Rev. 2017, 46, 2404-2420. (g) Raza, R.; Panja, A.; Mukherjee, M.; Chattopadhyay, P.; Ghosh, K. Dosimetric Chromogenic Probe for Selective Detection of Sulfide via Sol-Gel Methodology. ACS Omega 2018, 3, 17319-17325. (h) Panja, A.; Ghosh, K. Triazole-amide isosteric pyridine-based supramolecular gelators in metal ion and biothiol sensing with excellent performance in adsorption of heavy metal ions and picric acid from water. New J. Chem. 2019, 43, 934945.

(8) (a) Okesola, B. O.; Smith, D. K. Applying low-molecular weight supramolecular gelators in an environmental setting - self-assembled gels as smart materials for pollutant removal. Chem. Soc. Rev. 2016, 45, 4226-4251. (b) Panja, A.; Ghosh, K. Diaminomalenonitriledecorated cholesterol-based supramolecular gelator: aggregation, multiple analyte (hydrazine, $\mathrm{Hg}^{2+}$ and $\mathrm{Cu}^{2+}$ ) detection and dye adsorption. New J. Chem. 2018, 42, 13718-13725. (c) Mehwish, N.; Dou, X.; Zhao, Y.; Feng, C.-L. Supramolecular fluorescent hydrogelators as bio-imaging probes. Mater. Horiz. 2019, 6, 14-44. (d) Mayr, J.; Saldías, C.; Díaz Díaz, D. Release of small bioactive molecules from physical gels. Chem. Soc. Rev. 2018, 47, 1484-1515. (e) Christoff-Tempesta, T.; Lew, A.; Ortony, J. Beyond Covalent Crosslinks: Applications of Supramolecular Gels. Gels 2018, 4, 40. (f) Li, J.; Geng, L.; Wang, G.; Chu, H.; Wei, H. Self-Healable Gels for Use in Wearable Devices. Chem. Mater. 2017, 29, 8932-8952.

(9) (a) Panja, S.; Patterson, C.; Adams, D. J. TemporallyProgrammed Transient Supramolecular Gels. Macromol. Rapid Commun. 2019, 40, 1900251. (b) Dastidar, P. Designing Supramolecular Gelators: Challenges, Frustrations, and Hopes. Gels 2019, 5, 15. (c) Panja, S.; Adams, D. J. Gel to gel transitions by dynamic self-assembly. Chem. Commun. 2019, 55, 10154-10157. (d) Echeverria, C.; Fernandes, S.; Godinho, M.; Borges, J.; Soares, P. Functional Stimuli-Responsive Gels: Hydrogels and Microgels. Gels 2018, 4, 54 .

(10) (a) Rajasekar, M.; Das, T. M. Synthesis, characterization and gelation studies of a novel class of rhodamine based $\mathrm{N}$-glycosylamines. RSC Adv. 2014, 4, 30976-30983. (b) Saha, S.; Chhatbar, M. U.; Mahato, P.; Praveen, L.; Siddhanta, A. K.; Das, A. Rhodaminealginate conjugate as self indicating gel beads for efficient detection and scavenging of $\mathrm{Hg}^{2+}$ and $\mathrm{Cr}^{3+}$ in aqueous media. Chem. Commun. 2012, 48, 1659-1661.

(11) Chou, P.-T.; Wu, G.-R.; Wei, C.-Y.; Cheng, C.-C.; Chang, C.P.; Hung, F.-T. Excited-State Amine-Imine Double Proton Transfer in 7-Azaindoline. J. Phys. Chem. B 2000, 104, 7818-7829.

(12) (a) Byrne, P.; Turner, D. R.; Lloyd, G. O.; Clarke, N.; Steed, J. W. Gradual Transition from NH..Pyridyl Hydrogen Bonding to the NH... Tape Synthon in Pyridyl Ureas. Cryst. Growth Des. 2008, 8, 3335-3344. (b) Qureshi, N.; Yufit, D. S.; Steed, K. M.; Howard, J. A. K.; Steed, J. W. Anion hydrogen bonding from a "revealed" urea ligand. CrystEngComm 2016, 18, 5333-5337. (c) Meazza, L.; Foster, J. A.; Fucke, K.; Metrangolo, P.; Resnati, G.; Steed, J. W. Halogenbonding-triggered supramolecular gel formation. Nature Chem 2012, 5, 42. (d) Ghosh, K.; Panja, S.; Bhattacharya, S. Naphthalene linked pyridyl urea as a supramolecular gelator: a new insight into naked eye detection of I- in the gel state with semiconducting behaviour. RSC Adv. 2015, 5, 72772-72779.

(13) (a) Applegarth, L.; Clark, N.; Richardson, A. C.; Parker, A. D. M.; Radosavljevic-Evans, I.; Goeta, A. E.; Howard, J. A. K.; Steed, J. 
W. Modular nanometer-scale structuring of gel fibres by sequential self-organization. Chem. Commun. 2005, 5423-5425. (b) Byrne, P.; Lloyd, G. O.; Applegarth, L.; Anderson, K. M.; Clarke, N.; Steed, J. W. Metal-induced gelation in dipyridyl ureas. New J. Chem. 2010, 34, 2261-2274. (c) Panja, S.; Ghosh, S.; Ghosh, K. Pyridine/pyridinium symmetrical bisamides as functional materials: aggregation, selective sensing and drug release. New J. Chem. 2018, 42, 6488-6497. (d) Qin, L.; Wang, P.; Guo, Y.; Chen, C.; Liu, M. Self-Assembled Soft Nanomaterials Via Silver(I)-Coordination: Nanotube, Nanofiber, and Remarkably Enhanced Antibacterial Effect. Adv. Sci. 2015, 2, 1500134. 